DOI: https://doi.org/10.31392/NZ-npu-145.2019.04

УДК 378.147

Гільтай Л. С.

\title{
ВПЛИВ ЦИФРОВИХ ОСВІТНІХ ТЕХНОЛОГІЙ НА СУЧАСНИЙ СТАН ВИЩОЇ ОСВІТИ
}

У статті розглядаються питання впливу циифрових освітніх технологій на сучасний стан вищої освіти. Проаналізований досвід вітчизняних $i$ зарубіжних дослідників щзодо вивчення впливу ичифрових освітніх технологій на якість освітнього процесу. В статті наголошується, що Стратегія розвитку національної системи освіти формується адекватно сучасним інтеграційним і глобалізаційним прочесам, вона передбачає стійкий рух і розвиток Украйни в першій чверті XXI століття, інтеграцію національної системи освіти в європейський та світовий освітній простір. Від системи освіти вимагається підготовка висококваліфікованих фахівиів. Багато країн зараз розглядають освоєння інформаційних і комунікаційних технологій як ключовий елемент базової освіти. Стрімкий розвиток IКТ та їх проникнення в усі сфери життя суспільства вимагає не просто підвищення рівня комп'ютерної грамотності випускників 3ВО, а формування інформаційно-комунікаційної компетентності (IКК) студента, яка забезпечує рівноправну участь фахівия в глобальному інформаційному суспільстві $і$ сприяє розширенню можливостей прачевлаштування. Формування IKK студентів ЗВО, особливо педагогічних спеціальностей, $\epsilon$ в даний час однією з найбільш актуальних завдань в системі вищої професійної освіти. Це пов'язане в периу чергу з міжнародними прочесами: зближенням украӥнської вищої освіти з європейською в рамках Болонського процесу, глобалізацією $i$ інтернаціоналізацією культурного та інформаційного світового простору. Аналіз професійної освіти в Україні і європейських краӥнах говорить про те, щьо иифрові освітні технології $\epsilon$ основними та провідними складовими підготовки майбутніх фахівців комп'ютерних технологій. В статті акцентується, щзо зміни в вищий освіті поряд з динамічною $і$ часто невизначеною інформаційною екосистемою, в якій всі ми працюємо і живемо, вимагає нової уваги, щоб зосередитися на основоположних ідеях про июо екосистему. Істотні зміни, пов'язані з формуванням нового типу суспільного устрою - інформаційного суспільства, означають: орієнтацію на знання, цииррову форму представлення об'єктів, інноваційну природу $i$ віртуалізацію виробництва, динамізм соиіальних прочесів, оиінку ефективності особистості як людини, щзо володіє інформачійно-комунікачійними технологіями.

Ключові слова: вища освіта, якість освіти, иифрові освітні технології, майбутній фахівець, професійна діяльність.

Реалізація основних напрямків модернізації освіти вимагає переосмислення та визначення, які засоби навчання найбільш ефективні для розвитку якості особистості. Як наголошується в Комюніке "Всесвітньої конференції ЮНЕСКО з вищої освіти 2009 р. підготовка фахівців, яку сьогодні здійснюють 3ВО повинна відповідати потребам суспільства і одночасно передбачати їх" [8]. Формування сучасної системи освіти відбувалось в період XX столітті під впливом стрімкої індустріалізації та розвитком господарського комплексу країни. Основною метою розвинених країн наприкінці XX століття стало прискорити перехід від постіндустріального до сучасного етапу розвитку людства - де головним аспектом $€$ інформатизація суспільства, провідними ресурсами якого виступають знання та інформація. 
Питанням інфоорматизації освіти, впровадження новітніх інфоормаційнокомунікаційних технологій в освітню ссреру в Україні приділяється доволі значна увага. Зокрема, ухвалено Закони України: "Про національну програму інформатизації” [6], “Про основні засади розвитку інфоормаційного суспільства в Україні" [7]; Впровадження IКТ в навчальний процес в своїх дослідженнях розглядали і вчені України, інших країн СНД, а саме В. Биков, А. Веліховская, М. Головань, І. Гевко, М. Жалдак, В. Ізвозчиков, І. Луцик, А. Коваль, Н. Морзе, П. Образцов, А. Пеньков, О. Потапчук, С. Раков, А. Співаковський та багато інших. Дидактичні та психологічні аспекти застосування IКT в навчанні знайшли відображення в роботах В. Безпалько, В. Ляудіс, Ю. Машбіц, А. Пишкало, І. Синельник, С. Смирнова та інших дослідників.

Як зазначає колишній міністр освіти і науки України Станіслав Ніколаєнко у своїй статті, що "Вже зараз інформаційні та комунікаційні технології (IКТ) складають значну частку світового виробництва та ведуть до суттєвого перерозподілу як ринку праці та освітніх послуг. Зокрема, розвиток єдиного Європейського освітнього простору в рамках Болонського процесу істотно підвищує роль ІКТ в освіті, що зумовлено сучасною світовою тенденцією до створення глобальних відкритих освітніх та наукових систем, які дозволяють, 3 одного боку, розвивати систему накопичення і поширення наукових знань, а 3 інший - надавати доступ до різних інфоомаційних ресурсів широким верствам населення"[9]. Як зауважує Е. Войжітскі “Треба пам'ятати: цифррові технології це як мастило, вони допомагають освіті "ковзати", роблять його простіше, швидше і зручніше" [13]. Однак, як сказано в середньостроковій стратегії ЮНЕСКО, "Систем освіти, що спиралися на вимоги другої половини XX століття, вже не адекватні реаліям знань XXI століття" [11]. Серед гострих проблем, що стримують розвиток і не дають можливості забезпечити нову якість освіти, яка відповідає реаліям сьогодення слід зазначити наступні:

- освітні послуги не доствтньо відповідають вимогамта суспільства та запити стейкхолдерів та потребам ринку праці;

- відсутніть або обмеженість доступу отримання якісних освітніх послуг певних категорій населення (діти з особливими освітніми потребами, сльські діти, обдарована учнівська молодь, діти вимушені переселенці тощо);

- структура і зміст профресійно-технічної, вищої і післядипломної освіти недостатньо зорієнтований на потреби ринку праці та девірсифікацію економіки;

- повільне впровадження в навчально-виховний процес інноваційних та інформаційно-комунікаційних технологій;

- досить повільне здійснення гуманізації, екологізації та інформатизації системи сучасної освіти.

Визначити особливості впливу цифрових освітніх технологій на сучасний стан вищої освіти.

Стало очевидним, що, використовуючи тільки традиційні методи навчання вирішити ці завдання досить важко. В якості одного з ефективних засобів розвитку пізнавального інтересу сьогодні виступають інформаційнокомунікаційні технології. 
Слід зазначити, відомий американський футуролог Томас Фрей в доповіді під назвою "2 мільярди робочих місць зникнуть до 2030 року” (це приблизно половину всіх робочих місць на планеті) висловив упевненість, що менше, ніж за 20 років зникне майже 50 відсотків профресій, через непотрібність, при цьому з'явиться безліч якісно нових вакансій. Академічний світ, зазначив футуролог, повинен бути готовий до прийдешніх трансформацій, які ближче, ніж нам здається [16]. Ось професії, які, на думку Фрея, повинні зникнути [14]: учитель, тренер (як ментор, головна мета якого - загальний розвиток учня), викладач. Професії, які будуть затребувані: тренер (як "коуч", головна мета якого досягнення учнем конкретної, чітко поставленої мети), проектувальник освітніх курсів, співробітники освітніх таборів (освітній табір в даному випадку - це не установа освіти, а форма навчання, яка передбачає освоєння нових знань i навичок в польових умовах). Ми не повністю поділяємо прогнози футуролога, але звернути увагу на тенденції в змінах профресій, мабуть, корисно. Томас Фрей говорить про масовий перехід на онлайн-навчання. Він упевнений і в цьому з ним наша думка розходиться, що класичні університети будуть неспроможні конкурувати з відкритими курсами, що знаходяться в мережі у вільному доступі.

В одній із своїх праць Томас Фрей [17], детально проаналізував охарактеризував провідні тенденції, притаманні для освіти майбутнього. У числі основних трендів "new era of education" він зазначив:

- Переорієнтація освітнього процесу: трансформація акцентів від teachercentric (викладання) до learningcentric (навчання). Роль вчителя змінюється: в сучасному світі, де інфрормаційні потоки стають майже не контрольованими, одна людина не здатна претендувати на роль абсолютного авторитету і не може задовольнити потребу іншої людини в актуальному вичерпному знанні про предмет. Щоб отримати ґрунтовні знання, слід взаємодіяти з багатьма експертами, свого роду зібрати картинку знання з наукових пазлів, кожен з яких надає свою інформацію, але не вичерпує своєю індивідуальністю поле проблемних питань дослідження. Відкриті навчальні матеріали включають текст, зображення, аудіо, відео, інтерактивні симуляції та ігри, які можуть вільно використовуватися, а також повторно використовуватися по-новому ким завгодно в усьому світі. В майбутньому вчителя перейдуть від експертів по темам до ролі, в якій вони будуть діяти як гіди і тренери.

- Навчання в будь-де і будь-коли, тобто без обліку територіального або тимчасового чинника. Відмова від класно-урочної та лекційно-аудиторного роботи на користь дистанційного навчання, онлайн-курсів, високотехнологічних інструментів. Експерти будуть створювати навчальні програми, і учні навчатимуться в будь-який час або в будь-якому місці в зручному для них темпі, вивчаючи теми, які їм цікаві. Важливі нові точки дотику для нашого розуму включають в себе наші комп'ютери, електронні газети, відео-журнали, мобільні телефони, МРЗ-плеєри, відеоігри, твори мистецтва та багато іншого.

Епоха гіперіндівідуалізма. Сучасна людина все рідше прагне рівнятися на сусіда, не хоче "бути таким, як усі". Він прагне знайти рішення, яке дозволило б 
йому виділитися. Віртуальна реальність дозволяє людині знаходити таке особисте рішення для саморепрезентації. Не стане винятком і освітній процес: кожен захоче обрати для себе оптимальну і привабливу траєкторію навчання навчання.

Перехід психології споживача до психології творця від. Над швидкі темпи розвитку Інтернет-ресурсів дозволяють людині, навіть з опосередкованими вміннями та можливостями, генерувати контент, створювати щось нове, ділитися результами своєї творчості з багатьма іншими користувачами, говорить лише про одне - людина, у якої є доступ до мережі, $є$ потенційним творцем медіареальності.

Експоненціальне зростання інформації. Інформація настільки численна, що ми відчуваємо, що ми тонемо в ній, відбувається інформаційне перевантаження. Важливо звернути увагу на мінливі розміри інформації, а також на її обсяг [5].

Закон України “Про вищу освіту” (Стаття 58, п. 1.4) зобов'язує науковопедагогічних працівників "розвивати в осіб, які навчаються у вищих навчальних закладах, самостійність, ініціативу, творчі здібності” [10].

Цифрові технології - невід'ємна частина сучасного навчального процесу.

Провідний український науковець Валерій Биков вважає: “Методологія та методи педагогічних досліджень класичної педагогіки вимагають перегляду і вдосконалення в напрямку сучасних тенденцій розвитку навчально-виховного процесу, потреб і інтересів всіх його суб'єктів. Якісно поліпшити ситуацію, на наше переконання, може теоретико-методологічне обґрунтування нової галузі педагогічного знання - цифровий гуманістичної педагогіки, яка інтегрує біо- і техно, і роз'яснює, яким чином організовувати навчальний процес в умовах його протікання в реально-віртуальному просторі" [2].

Дослідник стверджують, що "цифрова гуманістична педагогіка - не просто новий шлях навчання, її поява зумовила виникнення нової освітньої парадигми, а також становлення наукової сфери, швидко розвивається і мотивує виникнення дискусій і нового педагогічного мислення" [2]. Як зазначає В. Биков, підхід до формулювання і визначення категорії "цифрова гуманістична педагогіка" пояснюється наступним чином [3]:

- в цифровому суспільстві педагогіка повинна враховувати вплив сучасних цифрових технологій на освітні процеси, тому і прийнято слово "цифрова";

- головним завданням педагогіки є освітній розвиток особистості, яка у вітчизняній гуманістичної традиції ґрунтується на філософських ідеях кордоцентризму Г. Сковороди, педагогіки благодійності Івана Зязюна, педагогіки серця В.Сухомлинського, тому відповідно вжито слово "гуманістична".

Методологічні основи цифрової гуманістичної педагогіки, наголошує В. Биков відображені в наступних положеннях [3]:

- застосування IKT в різних формах і видах навчальної діяльності різних вікових груп учнів повинні бути спрямовані на надання навчально-виховного процесу пізнавально-творчих характеристик та забезпечувати, відкритість, 
гнучкість, диференціацію, індивідуалізацію, комфортність, створювати ареал привабливості для освітнього розвитку громадян суспільства безперервного навчання;

- розвиток у вчителів інтегрованого мислення, спрямованого на сприйняття, проектування, реалізацію і оцінки навчального процесу, що відбувається шляхом об'єднання людських ресурсів і ІКТ, є основною умовою забезпечення, в інформаційному суспільстві, якості освіти;

- важливим мотиваційним фактором високоякісної професійної діяльності $€$ усвідомлення педагогами можливостей IКТ для застосування та створення позитивної педагогічної реальності;

- вміння вчителя розширювати канали передачі, сприйняття і відтворення інформації за допомогою застосування IКT суттєво підвищують дію пізнавально-активного впливу на учнів, покращують рівень засвоєння ними інфрормаційної візуалізації;

- позитивний потенціал пізнавально-активного впливу значно зростає, якщо учні будуть засвоювати інформаційну візуалізацію через застосування(апробацію) з різними IKT, що забезпечує творчу діяльність в інтегрованої (реальною і віртуальною) навчальному середовищі;

- досконале застосування ІІКТ збільшує операційні можливості педагогічної реальності, поглиблює її віртуальні характеристики, створює умови для духовно-креативного розвитку вчителів і учнів;

- для діагностики та оцінки якості навчально-виховного процесу, що відбувається в ході взаємодії людських і інформаційно-технологічних компонентів поряд з традиційними методами наукового дослідження повинні застосовуватися методи наукового аналізу діяльності учнів у віртуальному просторі.

Проблеми розвитку цифрової гуманістичної педагогіки висвітлені в роботах зарубіжних педагогів П. Андерсон, А. Бьорк, Дж. Браєр, С. Варнок, Р. Вітсон, С. Давидсон, Д. Джакацкі, Б. Хірша, Р. Ленема, Т. Клемент, П. Фіфе [3].

Дослідники дають таке визначення: “Цифрова гуманістична педагогіка це наука про закономірності створення позитивної інтегрованої педагогічної реальності за умови конвергенції фрізичного і віртуального (створеного за допомогою IKT) навчальних просторів (середовищ)" [3].

Для педагогів важливо усвідомлювати особливості перебігу педагогічних явищ при конвергенції фрізичного і віртуального просторів різних форм навчання, оцінювати розширення пізнавальних можливостей, що відкриваються в сучасних умовах [4].

Предметом дослідження цифрової гуманістичної педагогіки є вивчення і проектування навчально-пізнавальних дій, що відбуваються в результаті взаємодії суб'єктів педагогічного процесу з цифровими технологіями.

Виклики XXI століття до сучасної системи освіти вимагають розвиток цифрової грамотності на всіх рівнях безперервної освіти і відповідно цифрової компетентності викладачів, а також майбутніх магістрів освіти, які повинні навчитися проектувати цифрові наративи для підтримки фрормування умінь 
XXI століття, так званої групи "4 C": критичне мислення (Criticalthinking), комунікація (Communication), об'єднання (Collaboration) та креативність (Creativeness) [12].

Тимчук Л. на основі аналізу монографрії "Електронне слово: демократія, технологія і мистецтво", написаної Річардом Ленемом - професором Каліфрорнійського університету, старшим науковим співробітником Національного фоннду гуманітарних наук, обґрунтувала концептуальні засади використання цифрових наративів у вищому гуманістично-гуманітарній освіті [12]:

- студенти як жителі цифрового світу живуть у всесвіті зовсім відмінною від всесвіту людей старшого покоління. Вони сприймають звуки і форми як взаємозамінні, і їм здається звичною наявність комп'ютерів, де всі сигнали органів чуття можна перекроїти за бажанням, досягти творчої самореалізації на основі використання цифрових технологій;

- в сучасних реаліях френомен електронного слова, цифрового тексту обов'язково повинні визнати, як щось дійсно нове, що свідчить про інтенсивність конвергенції цифрової технології з гуманітарними предметами, демократизацією освіти;

- цифровий текст відрізняється від друкованого на паперовому носії тексту, стійкого і авторитарного, інтерактивністю, динамічністю і здатністю поєднувати слово з образом і звуком;

- цифровий текст - це твір мистецтва, який завжди стимулює до гри зі звичайним досвідом (змінити текст, додати зображення, звук і т.д.)

Таким чином, можна сміливо констатувати, що цифрові технологіїневід'ємна частина сучасного навчального процесу. Європейська комісія працює над декількома політичними ініціативами з метою модернізації освіти і навчання, забезпечує фінансування досліджень та інновацій, щоб просувати цифрові технології, що використовуються для навчання [3].

"Цифрова технологія збагачує навчання різними способами і пропонує можливості навчання, які повинні бути доступні для всіх. Це відкриває доступ до великої кількості інфрормації і ресурсів". “Цифрова трансформація в Європі прискориться завдяки швидкому просуванню нових технологій, таких як штучний інтелект, робототехніка, хмарні обчислення і блокування.

"Хоча існує безліч можливостей, що виникають в результаті цифрових перетворень, сьогодні найбільший ризик - це суспільство, погано підготовлене до майбутнього".

Ще 7 грудня 2016 року Європейська комісія прийняла “Повідомлення про поліпшення і модернізації освіти "з метою забезпечення високого якості освіти для всіх, зокрема, підкреслюючи переваги цифрових технологій для надання нових способів навчання. "Цифрове перетворення змінює ринок праці $\mathrm{i}$ вимагає нових навичок. Цифрові технології також будуть пропонувати нові способи навчання, якщо буде забезпечений адекватний доступ до цих технологій. Щоб скористатися перевагами цих тенденцій, системи освіти і навчання повинні краще реагувати на ці мінливі реалії ". "Забезпечення високої якості освіти - це завдання, яке ніколи не завершується: вона потребує 
постійної уваги, поліпшення та адаптації”. “Якість викладання є ключовим фактором підвищення якості вищої освіти" - зазначається в“ Повідомлення ...”.

Слід зауважити, що поряд з терміном “цифрові технології” в XXI столітті з'явилися такі поняття: цифровий розрив, цифрова нерівність, цифрова нерівність. "Між державами-членами ЄС та всередині нього існує постійний розрив, зокрема щодо цифровий інфраструктури та навичок, що перешкоджає інклюзивної зростання ".

Суть даних термінів полягає в тому, що вони позначають різницю в можливостях доступу до інформації та до утворення для різних категорій населення, вікових та соціальних груп. Оскільки інформаційні канали переміщуються в інтернет, відсутність у якоїсь групи людей доступу до глобальної мережі або невміння користуватися ІКТ автоматично означають появу цифрового розриву. Крім того, недолік інтересу дівчаток до продовження досліджень інформаційних і комунікативних технологій, науки, техніки, математики залишається явною проблемою. Це призводить до втрати соціальних і економічних можливостей і ризиків, що підсилюють гендерна нерівність. У зв'язку з цим в освіті виникають ще такі проблеми [1].

Нерівні можливості в учнів в отриманні інформації, відсутність у окремої групи навичок, досвіду мережевого спілкування і складності в організації онлайн-навчання для підтримки навчального процесу через труднощі використання домашніх ресурсів.

Широко спостерігається розрив між студентами, які володіють навичками використання IКT, інтернет-серфінгу і комунікації в соціальних мережах, і окремими викладачами, які навіть не розуміють, що представляють ці поняття. Звідси - відсутність взаєморозуміння між учнем і педагогами, неможливість організації співпраці викладачів і учнів, відсутність перспектив для забезпечення індивідуального підходу до учнів.

Поширений розрив між педагогами, постійно розвивають свої навички в області використання IКT, і інший частиною викладачів, що не користується інтернетом взагалі або користується дуже мало. У зв'язку з цим - відсутність вільного обміну інформацією і простору для відкритих дискусій, відсутність профресійної кооперації між викладачами, відсутність колективного запиту на підвищення кваліфікації, погіршення перспектив професійного зростання окремих викладачів.

Розрив між просунутими викладачами, постійно використовують ІКТ у викладанні, що живуть активної мережевої життям, і адміністрацією, вчасно не оцінивши інноваційний потенціал нових технологічних рішень і інструментів для управління вузом. Або навпаки, педагоги “не встигають” за інноваційними вимогами, що пред'являються більш неспокійним просунутим керівництвом. Звідси проблеми: неефективне управління вузом, погана зворотна зв'язок, висока ймовірність конфрліктів і управлінських криз, погіршення перспектив для проведення будь-яких перетворень у вузі.

Коли в навчальному закладі не розрізняють джерела цих проблем, "Відбувається підміна причин, що їх породжують, і починається безглузда діяльність, приречена на відсутність результатів при значному витрачання 
ресурсів - тимчасових, людських, матеріальних" [1].

"Інноваційний і підприємницький дух в освіті та навчанні повинен заохочуватися і підтримуватися з явною політичною готовністю і зусиллями по забезпеченню інноваційної роботи для всіх. Необхідно ділитися, обговорювати і просувати i, по можливості, розширювати інноваційну практику. Концепції, інструменти, методи, процеси, системне мислення і дизайнерське мислення повинні бути більш доступні для професіоналів в галузі освіти" [3]. У "Плані дій в області цифрового освіти" Європейської комісії основна увага також приділяється здійсненню і необхідності стимулювати, підтримувати і розширювати цілеспрямоване використання цифрової та інноваційної освітньої практики. План має три пріоритети:

1. Краще використання цифрових технологій для освіти і навчання.

2. Розробка відповідних цифрових компетенцій і навичок для цифрової трансформації.

3. Поліпшення освіти за рахунок кращого аналізу даних і передбачення.

Висновок. У висновку слід констатувати, що, аналізуючи наведені вище численні проблеми в освіті і вимоги до сучасних випускникам вузів, важко знайти приклади формування необхідних знань, умінь, навичок і компетенцій на основі традиційних форм і методів навчання. Тому слід звернути увагу на труднощі і перспективні шляхи формування інформаційно-комунікаційної компетентності майбутніх студентів педагогічних спеціальностей в процесі їх профресійної підготовки.

Стрімко змінюється середовищі вищої освіти поряд з динамічною і часто невизначеною інформаційної екосистемою, в якій всі ми працюємо і живемо, вимагає нового уваги, щоб зосередитися на основоположних ідеях про цю екосистемі. Істотні зміни, пов'язані з формуванням нового типу суспільного устрою - інформаційного суспільства, означають: орієнтацію на знання, цифрову форму представлення об'єктів, інноваційну природу і віртуалізацію виробництва, динамізм соціальних процесів, оцінку ефективності особистості як людини, що володіє інформаційно-комунікаційними технологіями.

\section{Використана література:}

1. Андреева Н. В., Рождественская Л. В., Ярмахов Б. Б. Шаг школы в смешанное обучение. Москва : Буки Веди, 2016. 280 с.

2. Биков В., Лещенко М. Цифрова гуманістична педагогіка відкритої освіти. Теорія $і$ практика упр. соиіал. системами : філософія, психологія, педагогіка, соџіологія. 2016. № 4. С. 115-130.

3. Цифрова гуманістична педагогіка : посіб. / Валерій Биков, Марія Лещенко, Лариса Тимчук ; НАПН України. Київ, 2017. 181 с.

4. Гевко I. В. Використання сучасних інформаційних технологій - основа професійного зростання педагога. Вісник Чернігівського начіонального педагогічного університету ім. Т. Г. Шевченка. 2018. № 151 (2). С. 10-14.

5. Гевко І. В. Значення інноваційних технологій при здійсненні інклюзивної освіти. Педагогічний альманах : збірник Комунального вищого навчального закладу Херсонська академія неперервної освіти Херсонської обласної ради. Херсон, 2018. Випуск № 37. С. 236-240.

6. Закон України “Про Національну програму інформатизації" від 04.02.1998 № 74/98-ВР [Електронний ресурс]. Режим доступу : http://zakon2.rada.gov.ua/laws/show/74/98-вр.

7. Закон України "Про Основні засади розвитку інформаційного суспільства в Україні на 2007-2015 роки” від 09.01.2007 № 537-V [Електронний ресурс]. Режим доступу : http://zakon2.rada.gov.ua/laws/show/537-16. 
8. Коммюнике [Электронный ресурс] : [принятое 8 июля 2009 г. на Все-мирн. конф. по высш. образованию "Новая динамика высшего образова-ния и научных исследований для изменения и развития общества", ЮНЕСКО, Париж, 5-8 июля 2009 г.]. Режим доступа: http://unesdoc.unesco.org/images/0018/001832/ 183277r.pdf (дата обращения: 4.05.2020). - Загл. с экрана.

9. Николаенко С. В освіті - інформаційна революція [Електронний ресурс]. Режим доступу: http://www.osvita.org.ua/distance/ukraine/add/01/ (дата звернення: 2.05.2020) - Загл. з экрану.

10. Про вищу освіту [Електронний ресурс]: Закон України від 01.07.2014 p. № 1556-VII : дата оновлення 01.01.2018. Законодавство України: [сайт]. Режим доступу: http://zakon5.rada.gov.ua/laws/show/1556-18.

11. 37 C/4. Среднесрочная стратегия, 2014-2021 гг. [Электронный ресурс]. UNESCO. - 2014 Режим доступа: http://unesdoc.unesco.org/images/0022/002278/227860r.pdf (дата обраще-ния: 3.05.2020). Загл. с экрана

12. Теоретико-методичні засади проектування цифрових нара-тивів у навчанні майбутніх магістрів освіти : автореф. дис. ... док. пед. наук. / Л. И. Тимчук ; НАПН України, Ін-т інформ. технологій i засобів навчання. Київ, 2017. -41 с.

13. Хайрутдинов Д. Образование на доверии [Электронный ресурс] : [беседа с американским педагогом Эстер Войжитски]. Erazvitie.org. - 2017. - 19 янв. - Режим доступа: http://erazvitie.org/article/obrazovanie_na_doveri i (дата обращения: 04.05.2020). - Загл. с экрана.

14. Чему учиться сегодня, если многих профессий скоро не будет? [Электронный ресурс]. Режим доступа: https://newtonew.com/opinion/future-education-thomas-frey (дата обращения: 04.05.2020). Загл. с экрана.

15. Digital Learning \& ICT in Education [Electronic resource]. Mode of access: https://ec.europa.eu/digitalsingle-market/en/policies/digital-learning-ict-educa-tion (access date: 04.05.2020). Title on screen

16. Frey T. 2 Billion Jobs to Disappear by 2030 [Electronic resource]. Futur-istSpeaker Thomas Frey. 2012. 3 Feb. Mode of access: http://www.fu-turistspeaker.com/business-trends/2-billion-jobs-to-disappear-by2030/ (ac-cess date: 04.05.2020). - Title on screen.

17. Frey T The Future of Education [Electronic resource]. FuturistSpeaker Thomas Frey. 2007. 3 Mar. Mode of access: http://www.futur-istspeaker.com/business-trends/the-future-of-education/ (access date: 04.05.2020). - Title on screen

\section{References:}

1. Andreeva N. V., Rozhdestvenskaya L. V., Yarmahov B. B. Shag shkoly v smeshannoe obuchenie. Moskva : Buki Vedi, 2016. $280 \mathrm{~s}$.

2. Bykov V., Leshchenko M. Tsyfrova humanistychna pedahohika vidkrytoi osvity. Teoriia i praktyka upr. sotsial. systemamy : filosofiia, psykholohiia, pedahohika, sotsiolohiia. 2016. № 4. S. 115-130.

3. Tsyfrova humanistychna pedahohika : posib. / Valerii Bykov, Mariia Leshchenko, Larysa Tymchuk ; NAPN Ukrainy. Kyiv, 2017. $181 \mathrm{s.}$

4. Hevko I. V. Vykorystannia suchasnykh informatsiinykh tekhnolohii - osnova profesiinoho zrostannia pedahoha. Visnyk Chernihivskoho natsionalnoho pedahohichnoho universytetu im. T. H. Shevchenka. 2018. № 151 (2). S. 10-14.

5. Hevko I. V. Znachennia innovatsiinykh tekhnolohii pry zdiisnenni inkliuzyvnoi osvity. Pedahohichnyi almanakh : zbirnyk Komunalnoho vyshchoho navchalnoho zakladu Khersonska akademiia neperervnoi osvity Khersonskoi oblasnoi rady. Kherson, 2018. Vypusk № 37. S. 236-240.

6. Zakon Ukrainy "Pro Natsionalnu prohramu informatyzatsii" vid 04.02.1998 № 74/98-VR [Elektronnyi resurs]. Rezhym dostupu : http://zakon2.rada.gov.ua/laws/show/74/98-vr.

7. Zakon Ukrainy "Pro Osnovni zasady rozvytku informatsiinoho suspilstva v Ukraini na 2007-2015 roky" vid 09.01.2007 № 537-V [Elektronnyi resurs]. Rezhym dostupu : http://zakon2.rada.gov.ua/laws/show/537-16.

8. Kommyunike [Elektronnyj resurs] : [prinyatoe 8 iyulya 2009 g. na Vse-mirn. konf. po vyssh. obrazovaniyu "Novaya dinamika vysshego obrazova-niya i nauchnyh issledovanij dlya izmeneniya i razvitiya obshestva", YuNESKO, Parizh, 5-8 iyulya 2009 g.]. Rezhim dostupa: http://unesdoc.unesco.org/images/0018/001832/ 183277r.pdf (data obrasheniya: 4.05.2020). Zagl. s ekrana.

9. Nykolaenko S. V osviti - informatsiina revoliutsiia [Elektronnyi resurs]. Rezhym dostupu : http://www.osvita.org.ua/distance/ukraine/add/01/ (data zvernennia: 2.05.2020) - Zahl. z эkranu. 
10. Pro vyshchu osvitu [Elektronnyi resurs]: Zakon Ukrainy vid 01.07.2014 r. № 1556-VII : data onovlennia 01.01.2018. Zakonodavstvo Ukrainy: [sait]. Rezhym dostupu: http://zakon5.rada.gov.ua/laws/show/155618.

11. 37 C/4. Srednesrochnaya strategiya, 2014-2021 gg. [Elektronnyj resurs]. UNESCO. - 2014. Rezhim dostupa: http://unesdoc.unesco.org/images/0022/002278/227860r.pdf (data obrashe-niya: 3.05.2020). Zagl. s ekrana

12. Teoretyko-metodychni zasady proektuvannia tsyfrovykh nara-tyviv u navchanni maibutnikh mahistriv osvity : avtoref. dys. ... dok. ped. nauk. / L. Y. Tymchuk ; NAPN Ukrainy, In-t inform. tekhnolohii i zasobiv navchannia. Kyiv, 2017. $41 \mathrm{~s}$.

13. Hajrutdinov D. Obrazovanie na doverii [Elektronnyj resurs] : [beseda s amerikanskim pedagogom Ester Vojzhitski]. Erazvitie.org. 2017. 19 yanv. Rezhim dostupa: http://erazvitie.org/article/obrazovanie_na_doveri i (data obrasheniya: 04.05.2020). Zagl. s ekrana.

14. Chemu uchitsya segodnya, esli mnogih professij skoro ne budet? [Elektronnyj resurs]. Rezhim dostupa: https://newtonew.com/opinion/future-education-thomas-frey (data obrasheniya: 04.05.2020). Zagl. s ekrana.

15. Digital Learning \& ICT in Education [Electronic resource]. Mode of access: https://ec.europa.eu/digitalsingle-market/en/policies/digital-learning-ict-educa-tion (access date: 04.05.2020). - Title on screen

16. Frey T. 2 Billion Jobs to Disappear by 2030 [Electronic resource]. Futur-istSpeaker Thomas Frey. 2012. 3 Feb. Mode of access: http://www.fu-turistspeaker.com/business-trends/2-billion-jobs-to-disappear-by2030/ (ac-cess date: 04.05.2020). Title on screen.

17. Frey T. The Future of Education [Electronic resource]. FuturistSpeaker Thomas Frey. 2007. 3 Mar. Mode of access: http://www.futur-istspeaker.com/business-trends/the-future-of-education/ (access date: 04.05.2020). Title on screen

\section{ГильтАЙЛ. С. Влияние цифровых образовательных технологий на современное состояние высшего образования.}

В статье рассматриваются вопросы влияния цифровых образовательных технологий на современное состояние высшего образования. Проанализирован опыт отечественных $и$ зарубежных исследователей по изучению влияния ичифровых образовательных технологий на качество образовательного прочесса. В статье отмечается, что Стратегия развития национальной системы образования формируется адекватно современным интеграционным и глобализационным прочессам, она представляет стабильное развитие и ориентацию Украинь направленную на интеграцию национальной системы образования в европейское и мировое образовательное пространство. От системы образования требуется подготовка высококвалифицированных специалистов. Многие страны сейчас рассматривают внедрение информационных и коммуникационных технологий как ключевой элемент базового образования. Стремительное развитие ИКТ и их проникновение во все сферы жизни общества требует не просто повышение уровня компьютерной грамотности випускникив ЗВО, а формирование информационно-коммуникачионной компетентности (ИКК) студента, что обеспечивает равноправное участие спечиалиста в глобальном информачионном обществе и способствует расширению возможностей трудоустройства. Формирование ИКК студентов ЗВО, особенно педагогических специальностей, является в настоящее время одной из наиболее актуальных задач в системе высшего профессионального образования. Это связано впервую очередь с международными проиессами: сближением украинского высшего образования с европейским в рамках Болонского процесса, глобализацией и интернационализацией культурного и информационного мирового пространства. Анализ профессионального образования в Украине и европейских странах говорит о том, что ичифровые образовательные технологии является основной ведущей и базовой составляющей подготовки будущих специалистов компьютерных технологий. Существенные изменения, связанные с формированием нового типа общественного устройства - информационного общества означают: ориентацию на знания, цифровую форму представления объектов, инновационную природу и виртуализацию производства, динамизм социальных процессов, оценку эффективности личности как человека, обладающего информационно-коммуникационными технологиями. 
Ключевые слова: высшее образование, качество образования, цифровые образовательные технологии, будущий специалист, профессиональная education.

GILTAY L. S. The impact of digital educational technologies on the modern state of higher

The article deals with the influence of digital educational technologies on the current state of higher education. The experience of domestic and foreign researchers in studying the impact of digital educational technologies on the quality of the educational process is analyzed. The article emphasizes that the Strategy for the development of the national education system is adequately shaped by modern integration and globalization processes, it envisages the steady movement and development of Ukraine in the first quarter of the 21 st century, the integration of the national education system into the European and world educational space. The education system requires the training of highly qualified specialists. Many countries are now considering the development of information and communication technology as a key element of basic education. The rapid development of ICTs and their penetration into all spheres of society requires not only increasing the level of computer literacy of graduates of HEI, but the formation of a student's Information and Communication Competence (ICC), which ensures equal participation of a specialist in the global information society and promotes employment opportunities. The formation of CCI students of the HEI, especially pedagogical specialties, is currently one of the most urgent tasks in the higher vocational education system. This is primarily related to international processes: the convergence of Ukrainian higher education with European within the Bologna process, globalization and internationalization of the cultural and information world space. Analysis of vocational education in Ukraine and European countries shows that digital educational technologies are the main leading of the basic components of the training of future computer specialists. The article points out that the rapidly changing environment of higher education, alongside the dynamic and often undefined information ecosystem in which we all work and live, requires new attention to focus on fundamental ideas about this ecosystem. Significant changes related to the formation of a new type of social structure - the information society, mean: knowledge orientation, digital representation of objects, innovative nature and virtualization of production, dynamism of social processes, assessment of the effectiveness of the individual as a person with information and communication technology.

Keywords: higher education, quality of education, digital educational technologies, future specialist, professional activity. with information and communication technology.

DOI: https://doi.org/10.31392/NZ-npu-145.2019.5

УДК 378.091.3:373.5.011.3-051]:78

Дуда І. Т., Ленд’єл-Сяркевич А. А., Сербін М. І.

\title{
ТЕАТРАЛІЗАЦІЯ ЯК ІННОВАЦІЙНА ТЕХНОЛОГІЯ \\ ВИКОНАВСЬКОЇ ІНТЕРПРЕТАЦІЇ У ПРОЦЕСІ ФАХОВОЇ ПІДГОТОВКИ МАЙБУТНІХ УЧИТЕЛІВ МУЗИЧНОГО МИСТЕЦТВА
}

\begin{abstract}
Характерною особливістю сучасної мистецької освіти в Україні стало посилення зв'язків між культурою та освітою, зумовлене тим, що саме культура фокусує систему ціннісних уявлень, які становлять основу
\end{abstract}

